\title{
Preface
}

In reply (January 9, 1956) to a young correspondent anxious to have Kafka explained to him, Hesse reiterated what he had always pointedly insisted upon:

He who is capable of really reading a writer ... will have his every question answered by the works themselves. . . . He [Kafka] depicts the dreams and visions of his lonely, difficult life . . . and it is these dreams and visions alone that should preoccupy us, and not the interpretations that sharp-witted interpreters can give these writings. This "interpreting" is an intellectual sport ... one that is good for clever people ... . who can read and write books about Black sculpture or twelve-tone music but who never get to the heart of a work of art because they stand at the gate fumbling with their hundred keys, blind to the fact that the gate is really not locked. ${ }^{1}$

Hesse was obviously far more touched by a sensitive reader's openhearted and open-minded response to literature than impressed by a critic's cerebrations, ingenious though they might be. The actual experiencing of literature was its absorption by readers and not its dissection by critics. A work of art was essentially its own explanation, it needed no elucidation. Hesse was clearly less than enchanted by those who wrote about literature.

Since I concur with this sentiment, though not fully and am somewhat taken aback by its hyperbolic statement, I feel obliged to account for my transgression. This book was not written in the belief that Hesse's readers required such "interpretations" to grasp his "dreams and visions," or that his literary spokesmen had to be improved upon. It was not this altruistic concern or conceit, nor the 


\section{$x$ / Preface}

seduction of "intellectual sport," but psychological necessity that provided the major impetus: my longtime ready absorption of Hesse's writings simply had to be balanced by organized afterthought. I had not only to take in but also to understand both Hesse and his work in order better to understand myself and literature. If perhaps I have not also remained standing before the open gate like Hesse's censured critics with their hundred unavailing keys, it is probably due to this combination of ready absorption and necessary reflection. But whether or not I have succeeded in entering the inner sanctum, the book has already served my own immediate purpose, and will in some measure also serve its own purpose in the community of scholars, of those "who can read and write about books about Black sculpture or twelve-tone music." It will exceed my expectations, though not my hope, should my book also manage to serve Hesse's wider community of readers, should it manage to extend and to deepen the Hesse-experience for the lay reader.

In my undertaking I was primarily intent upon revealing Hesse the person and his world of ideas, characterizing his writings in both their substance and form, and drawing attention to the intimate relationship between his life and his art. My object was to see Hesse as he was and not to imagine what he was, to try to understand his works as he himself understood them and not as I might prefer to understand them, and to shed some light on his creative process. To avoid literary myth and to make possible the literary study I had in mind, biography had to be corrected and expanded and previous critical coverage of both Hesse's writings and his sundry literary involvements considerably extended.

Apart from correcting and adding lesser biographical details and dates, I have given more than the usual attention to Hesse's marriages and his children, his analyst J. B. Lang, his circle of patrons, and to the many painters, composers, and writers among his friends; to his early familiarity with English, Scandinavian, Russian, and Italian literature, his immediate attraction to romanticism and rejection of naturalism, and his particular interest in Tolstoy and Dostoevsky, and in St. Francis of Assisi and Boccaccio; to his preoccupation with Nietzsche, Schopenhauer, and Jacob Burckhardt, and with Catholicism, the Middle Ages, and the Orient; to Pietism's impact upon Hesse's life, and childhood's imprint on his art; and to his watercolors and his privately marketed self-illustrated manuscript collections of poems. I have detailed Hesse's general attitude to politics, his own political views, and his sporadic sociopolitical involvements; his quar- 


\section{Preface / xi}

rel both with the militarists and pacifists during the First World War, his vilification by both the Nazis and refugee German Jews during the thirties, and his altercation with an American army officer in the autumn of 1945 with the resultant banning of his books by the German press in the American sector. I have focused upon Hesse's almost unreserved embrace of Freud and more hesitant acclaim of Jung, and upon their influence on his art; upon the role Hesse believed psychoanalysis could play in literature and should not play in literary criticism, and upon his reaction to the association of art and disease, and of genius and insanity. And I have also traced the repeated ebb and flow of Hesse's literary popularity both in Germany and abroad.

I have extended coverage of Hesse's literary activities as much as his biography, and my interest in his evolving life and a surmised closely corresponding evolution in both the substance and form of his art determined my chronological approach. I have drawn brief attention to generally unknown literary beginnings and first publications, have accorded each of Hesse's major tales individual treatment more or less commensurate in length with its significance, and have, albeit collectively more often than individually, accounted for many of his shorter narratives-the legends, Italianate tales, Swabian short stories, and fairy tales - works that have to date been all but ignored. I have characterized Hesse's poetry, scanned his sociopolitical essays, and studied his extensive work as a reviewer and editor. I have also drawn attention to Hesse's numerous travel reports and nature sketches, recollections and reflections, literary studies and congratulatory and memorial articles, autobiographical snippets and letters, and even to his comparatively few diary fragments and translations. Nor have I ignored Hesse's considerable corpus of unpublished material: tales, dramas, librettos, poems, fragments, literary plans, essays, letters, and diaries.

At the extremes of storytelling there are those writers who spin their yarns and those who document their lives. Hesse belongs to the latter. He had to write and he had to write about himself and there is little of the much he wrote that is not confessional in form and therapeutic in function. With rare exception, each of Hesse's major tales begins where the immediately preceding tale breaks off, scrutinizes and finds wanting its predecessor's concluding promise of better possibility, and then itself terminates abruptly on its own upbeat of new hope. These were Hesse's own serial appraisals of the self and assessments of life, milestones along his own erratic course of self-realization, and the different theories of art and various philos- 


\section{xii / Preface}

ophies argued in these works mirror Hesse's efforts to lend approbation to his own different adjustments to himself and to life and to make existence more bearable. But autobiography is not just confined to narrative substance, it permeates the very narrative fabric of Hesse's art, no less in his minor than in his major works. Hesse's protagonists are self-projections not only in their concerns, thoughts, and feelings, but even in their persons and experiences and, with rare exception, in the worlds in which they live and the circles in which they move. It is upon this autobiographical core that my study focuses. Concentration upon evolving self-realization, the foremost of Hesse's concerns, and upon life and art, the real and the ideal, erotic and social love, sensuality and spirituality, time and timelessness, multiplicity and oneness, aestheticism and social commitment, and middle-class Western culture-related and accompanying themes that evolve similarly from tale to tale-will, I hope, silhouette Hesse's variegated world of thought more sharply and make possible a better understanding of his works, singly and as an unbroken continuum; disclosure of the unusually personal texture of these works should provide a revealing glimpse into Hesse's workshop; and together these two foci may add something to our still limited understanding of the artistic personality and of the creative process.

But Hesse's tales are clearly not just a raw annotation of the self. Autobiography is only matrix and not product. Life transfiguredfantasized, poeticized, dramatized, and symbolized-becomes art with universal implications, and the art of Hesse's writings, like their concerns, evolved with his own evolving life in an upward and outward spiral. I have paid as much attention to this evolution of narrative manner as to evolving narrative matter. A young aesthete given to his dream world and purple prose becomes an "artist-burgher" intent upon adjustment and traditional poetic realism, and then a rebel-seeker determined to come to grips and to terms with himself and life at large and to push back the horizons of literary possibility. In my delineation of this progression, apart from genesis, biography, and substance, I have examined each of the major tales in terms of structure, mode of narration, description, and characterization; vocabulary, syntax, flow, and rhythm of sentences; symbolism, names, double self-projections, and various other of Hesse's literary devices and special features of form. I have accorded the earlier, more traditional, and less involved works much less attention than the novel and more demanding literary ventures beginning with Demian, and have treated Das Glasperlenspiel in a manner commensurate with its 
length, complexity, and significance. From all this I hope there emerges a telling portrait of Hesse the man and the artist, an informative characterization of his work, and a revealing exposure of the life and art relationship at its most intimate.

Since the number of Hesse enthusiasts and Hesse scholars to whom I am indebted in one way or another for this study is legion, I shall have to express my thanks without the usual mention of names. Besides these persons, I am particularly obliged to Hesse's sons Bruno and Heiner for biographical information, to Dr. Bernard Zeller for giving me free access to the Hesse-Nachlass in the SchillerNationalmuseum, and to the American Philosophical Society for a travel grant. 